\title{
Stereotypies in adults: a systematic review
}

\author{
Tanvi Shukla, Sanjay Pandey \\ Department of Neurology, Govind Ballabh Pant Postgraduate Institute of Medical Education and Research, New Delhi, India
}

\begin{abstract}
Stereotypies are abnormal involuntary non-goal-directed movement patterns or vocalisations which repeat continuously in the same fashion over a period of time and on multiple occasions and are typically distractible. Stereotypies are common in both children and adults, but they are extensively reviewed only in children. There are very few studies, mainly in the form of case reports and case series, focusing on stereotypies occurring in adults as part of different neurological disorders.

In adults, stereotypies can be both physiological and pathological. Common physiological stereotypies in adults are leg shaking, face touching, playing with pens or hair, nail biting, hand tapping, foot tapping, and body rocking. Pathological stereotypies in adults are associated with a variety of neuropsychiatric conditions like neurodegenerative disorders, viral encephalitis, autoimmune encephalitis, stroke, psychiatric illness, and drug use.

In this review, we focus on the various causes of stereotypic movements in adults, and their pathophysiology, clinical manifestations, and treatment.
\end{abstract}

Key words: stereotypy, physiological, autoimmune encephalitis, drugs, psychiatry, stroke

(Neurol Neurochir Pol 2020; 54 (4): 294-304)

\section{Introduction}

Stereotypy was defined by Edwards et al. as "a non-goal-directed movement pattern or vocalisation that is repeated continuously for a period of time in the same form and on multiple occasions, and which is typically distractible" [1].

The word 'stereotyped' means something which is typical or repeats in the same fashion. So, stereotypies are an abnormal involuntary movement which repeats rhythmically in the same fashion 'in a loop' for a long duration and at the expense of other movements. Stereotypies are more common at times of anxiety, excitement, stress, focused concentration, or boredom, and in blind and deaf children they are a version of coping mechanism in both overstimulating and understimulating environments [2]. They can be differentiated from tics in that stereotypy patients do not have an urge to do the movements, but they however feel gratified and pleased while performing them $[2,3]$. Stereotypies are distractible and can be easily suppressed by an external stimulus. However, these patients rarely make a conscious effort to quell movements $[1,4]$.

Stereotypies can be classified as simple stereotypies such as leg shaking, hair twirling, nail biting, teeth grinding, body rocking, thumb sucking or foot tapping, or as more complex stereotypies like hand waving, playing with hands or repeatedly opening and closing hands, hand posturing, head nodding, headbanging, repeatedly sitting down and getting up from a chair, finger wagging, pacing, lip smacking, chewing, mouth opening, self-biting and other self-injurious behaviours. Apart from motor stereotypies, there are also vocal or phonic stereotypies like humming, grunting, moaning, or repeating words and phrases $[1,3,4]$.

Stereotypies can also be classified as primary or secondary depending on the presence or absence of an underlying neurological or psychiatric disorder [5]. They are associated with various genetically determined neurodegenerative disorders or can be acquired secondarily to infectious or non-infectious encephalitis, stroke, or drug exposure. The main pathophysiological mechanism for the occurrence of stereotypies in an individual is a dysfunction of the cortico-striatal-thalamo-cortical pathways leading to dopaminergic overactivity and cholinergic/GABAergic underactivity causing abnormal involuntary movements [2].

Stereotypies are extensively reviewed in children, especially those with an autistic spectrum disorder or a pervasive developmental disorder, but the literature on stereotypies in 
adults is sparse. In this review, our focus will be on various conditions associated with stereotypies in adults.

\section{Methodology}

We searched the PubMed database on 31 March 2020 using the search terms "Adult-onset stereotypies", "Drug induced stereotypies" "Stereotypies in psychiatry", "Stereotypies in dementia", "Stereotypies in stroke", "Stereotypies in autoimmune disorders" and "Stereotypies in viral encephalitis". After excluding animal studies, we identified 2,552 articles for screening. After removing duplicates and articles in languages other than English, 110 articles were eligible for full text reading. Thirty-one articles were further excluded as they did not describe a motor or phonic stereotypy in detail. Finally, 79 articles were included for our detailed review [Fig. 1, Tab. 1].

\section{Stereotypies in adults}

Physiological stereotypies in adults

Physiological stereotypies are common in children, but rarely seen in adults. However, various studies have demonstrated that paediatric stereotypies may persist into adulthood
[6-8]. In a study by Harris et al. on 100 non-autistic children presenting with motor stereotypies, it was observed that only six children had a complete resolution of their stereotypies. The remaining 94 children had persistent stereotypies even in adulthood. Children with arm/ hand stereotypies and whose stereotypies initially persisted for more than a year had a greater chance of developing persistent stereotypies throughout adulthood than children with head-nodding stereotypies [6]. In children with persistent stereotypies, as the age advanced the stereotypies remained the same, improved, or became worse. In another study on 49 children (aged 9-20 years) with primary complex motor stereotypies, Oakley et al. reported that stereotypies were persistent in $98 \%$ of individuals in a long term follow up; $18 \%$ reported the appearance of new stereotypic movements, and $45 \%$ reported a change in their original stereotypic movements [7].

'Leg stereotypy disorder' is another movement disorder reported in adults and was first described by Jankovic in 2016 [9]. Stereotypic movements in this disorder are characterised by repetitive 1-4 Hz flexion-extension, abduction-adduction movements of the hip while people are seated with their feet resting on the floor. Stereotypic movements can also occur at knee or ankle joints while sitting cross-legged or sometimes

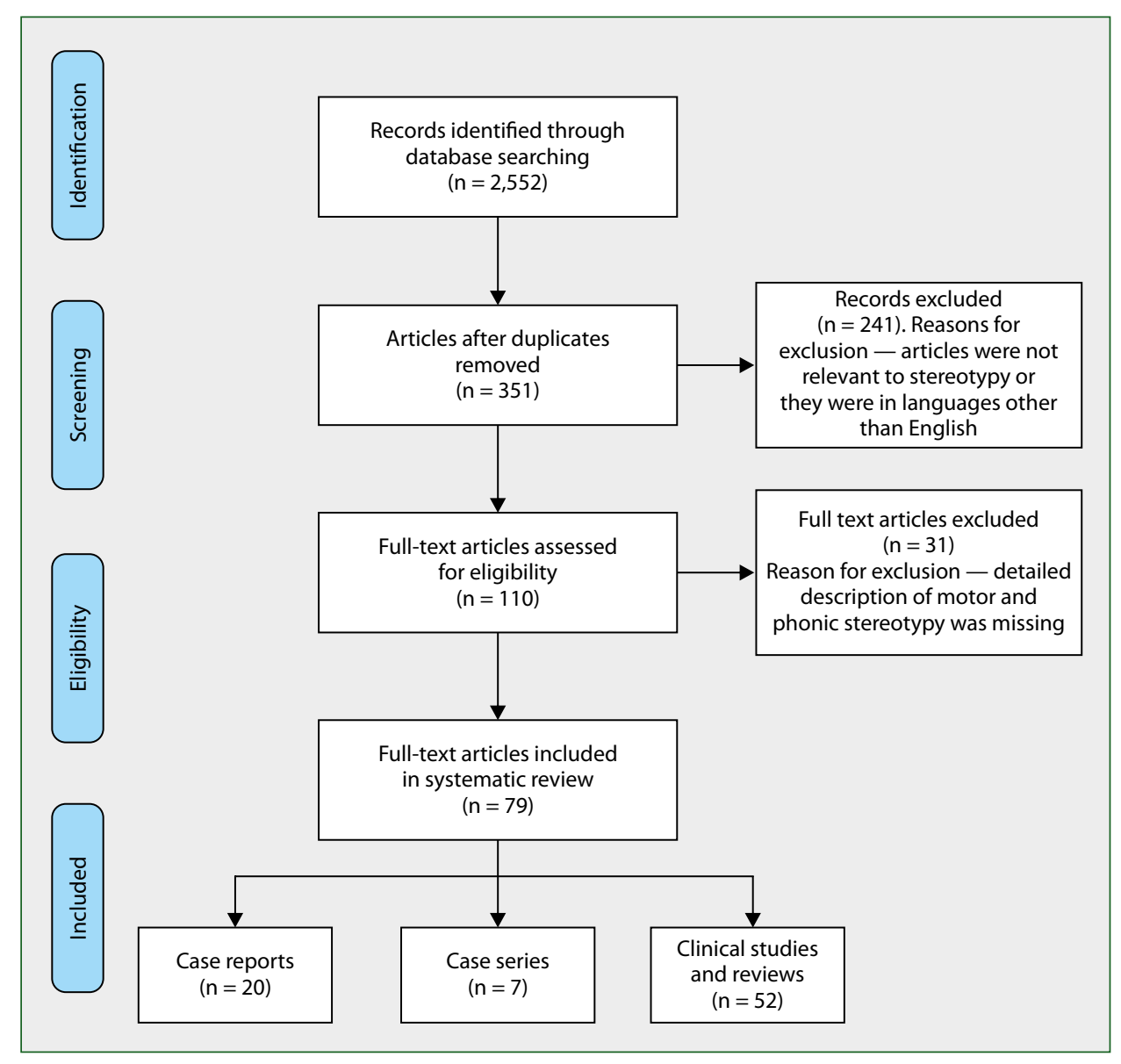

Figure 1. Search strategy for the systematic review 
Table 1. PubMed search (on 31 March 2020) results, using different search terms for 'Stereotypies in adults'

\begin{tabular}{lccc} 
Search term & Number of hits & $\begin{array}{c}\text { Relevant articles after remo- } \\
\text { ving duplication }\end{array}$ & Articles finally selected \\
\hline Adult-onset stereotypies & 132 & 33 & 13 \\
Drug induced stereotypies & 1,408 & 197 & 21 \\
Stereotypies in psychiatry & 773 & 48 & 11 \\
Stereotypies in dementia & 167 & 36 & 13 \\
Stereotypies in stroke & 48 & 20 & 12 \\
Stereotypies in autoimmune disorders & 21 & 14 & 6 \\
Stereotypies in viral encephalitis & 3 & 3 & 3 \\
Total & 2,552 & 351 & 79
\end{tabular}

people may just tap their feet on the ground while sitting. Also, there can be associated 'fidgeting' movements of hands and/or other body parts. These movements usually stop while standing or walking, but some patients may have a swaying movement on standing. Patients also report anxiety with the effort to stop the movements. Leg stereotypies are frequently familial, suggestive of a genetic origin. They may or may not be associated with anxiety or Attention Deficit Disorder [9]. A screening questionnaire and rating scale have been proposed for leg stereotypy disorder [9]. Although no definite treatment has been suggested, dopaminergic and GABAergic drugs have been used in some patients, with good improvement [9].

Physiological stereotypies have also been studied in college students [10]. In this study, the most common stereotypies were touching the face $(75 \%)$, playing with pens $(68.2 \%)$, and playing with hair (67\%). The least common stereotypy was sticking out the tongue (9.9\%) [10]. Another stereotypic movement disorder common in adults is a cheek-biting disorder characterised by compulsive biting of the cheeks, tongue, and lips leading to mucosal ulcerations [11]. It is more prevalent in those aged 35 to 44 , and is usually associated with increased anxiety and nervousness [11].

Stereotypic headbanging before sleep is a rhythmic movement disorder usually seen in children and rarely reported in adults. However, Chisholm and Morehouse reported two cases of headbanging in adults causing disturbed sleep and daytime somnolence. Both these patients had no other psychiatric comorbidity and they had an excellent response with clonazepam [12]. Another case with stereotypic headbanging in a 19-year-old boy was reported by Alves et al. This patient did not respond to benzodiazepines, but improved with imipramine (a tricyclic antidepressant) [13].

\section{Drug induced stereotypies}

Drugs are known to cause tics and stereotypies by altering dopaminergic activity in basal ganglia. Common groups of drugs associated with stereotypies are neuroleptics, amphetamine, cocaine, methylphenidate, levodopa, dopa agonists, apomorphine, morphine, bupropion, disulfiram, and anticholinergics like benztropine. Abnormal movements associated with the use of neuroleptics can be grouped under acute reactions, for example acute dystonia, and chronic reactions such as tardive syndromes [14]. Although tardive dyskinesia (TD) or tardive stereotypies are more commonly associated with first-generation antipsychotics, one series has demonstrated that around $3.4 \%$ of patients developed TD with aripiprazole, which is a third-generation antipsychotic [15].

Stereotypic movements in 'classic tardive dyskinesia' typically affect the orolingual region causing repetitive, rhythmic, stereotyped movements like lip smacking, puckering, chewing, tongue protrusion, and tongue movements inside the mouth. Rarely, stereotypic movements may also involve limbs, trunk, and respiratory muscles. 'Tardive stereotypy' is a term exclusively used for these patients with the involvement of limb and body parts other than the orolingual region. They usually manifest as repetitive leg movements, flexion-extension of toes, feet tapping, and head, pelvis, or body rocking. Sometimes they can also produce respiratory disturbances because of the involvement of respiratory muscles. An unusual tardive stereotypy in the form of stereotypic hand clasping has also been described [16]. Many pathophysiological mechanisms have been proposed regarding the genesis of $\mathrm{TD}$, but the most plausible theory suggests that chronic use of a dopamine D2 receptor blocker causes hypersensitisation of D2 receptors, resulting in the disinhibition of globus pallidus and substantia nigra, leading to the production of hyperkinetic movement disorders including tardive stereotypies $[15,17]$.

Multiple treatment strategies are used for the treatment of tardive stereotypy [14]. The first step is to taper off the offending agent and discontinue drugs that can exacerbate tardive stereotypy like anticholinergics. If antipsychotics are required, then the patient should be switched to atypical antipsychotics with lower D2 receptor blocking action, like clozapine and quetiapine. The first-line agents for the treatment of tardive dyskinesia or tardive stereotypy are vesicular monoamine transporter 2 (VMAT 2) inhibitors including tetrabenazine, deutetrabanazine and valbenazine. They deplete presynaptic dopamine by decreasing the storage and release of dopamine and other monoamines from presynaptic neurons by inhibiting VMAT 2 on presynaptic vesicles. Tetrabenazine has been used 
Table 2. Clinical characteristics of stereotypies in adults reported in literature

\begin{tabular}{|c|c|c|c|c|}
\hline \multicolumn{2}{|c|}{ Aetiology of stereotypies } & \multirow{2}{*}{$\begin{array}{l}\text { Onset and course of stereotypies } \\
\text { Delayed onset stereotypies started by } \\
\text { age } 3 \text { and persisting in around } 95.3 \% \\
\text { in adulthood. The type and severity of } \\
\text { stereotypies changed in adulthood as } \\
\text { compared to childhood }\end{array}$} & \multirow{2}{*}{$\begin{array}{l}\text { Treatment given } \\
\text { Behavioural therapy, pharmacotherapy } \\
\text { in the form of clonidine, risperidone, } \\
\text { oxcarbazepine, fluoxetine, topiramate, } \\
\text { pimozide, levetiracetam, sodium valproate, } \\
\text { carbamazapine, clonazepam, phenytoin, } \\
\text { and acetazolamide }\end{array}$} & \multirow{2}{*}{$\begin{array}{l}\text { Outcome } \\
\text { No improve- } \\
\text { ment in stereo- } \\
\text { typies }\end{array}$} \\
\hline $\begin{array}{l}\text { Physiological } \\
\text { stereotypies } \\
\text { in adults }\end{array}$ & $\begin{array}{l}\text { Paediatric stereo- } \\
\text { typies persisting in } \\
\text { adults [6-8] }\end{array}$ & & & \\
\hline & $\begin{array}{l}\text { Leg stereotypy } \\
\text { disorder [9] }\end{array}$ & $\begin{array}{l}\text { Delayed onset persistent non progressive } \\
\text { stereotypies mostly of genetic origin }\end{array}$ & Dopaminergic and GABAergic drugs & $\begin{array}{l}\text { Improvement } \\
\text { in stereotypic } \\
\text { movements }\end{array}$ \\
\hline & $\begin{array}{l}\text { Stereotypic beha- } \\
\text { viours in college } \\
\text { students [10] }\end{array}$ & $\begin{array}{l}\text { Delayed onset, persistent non progressive, } \\
\text { non- disabling stereotypies }\end{array}$ & Clomipramine & Improvement \\
\hline & Cheek biting [11] & $\begin{array}{l}\text { Delayed onset, non-progressive stereoty- } \\
\text { pies, causing mouth ulcerations, associa- } \\
\text { ted with anxiety }\end{array}$ & Fluvoxamine & $\begin{array}{l}\text { Significant } \\
\text { improvement }\end{array}$ \\
\hline & $\begin{array}{l}\text { Headbanging du- } \\
\text { ring sleep }[12,13]\end{array}$ & $\begin{array}{l}\text { Delayed onset stereotypies since birth, } \\
\text { persisting into adulthood leading to sleep } \\
\text { disruption }\end{array}$ & $\begin{array}{l}\text { Benzodiazepines, } \\
\text { tricyclic antidepressants (imipramine) }\end{array}$ & $\begin{array}{l}\text { Responded } \\
\text { excellently }\end{array}$ \\
\hline \multirow[t]{4}{*}{$\begin{array}{l}\text { Drug induced } \\
\text { stereotypies }\end{array}$} & $\begin{array}{l}\text { Tardive stereoty- } \\
\text { pies [14-20] }\end{array}$ & $\begin{array}{l}\text { Delayed onset stereotypies started after } \\
\text { a few months of taking DRBAs and lasts for } \\
\text { at least few weeks after stopping DRBAs }\end{array}$ & $\begin{array}{l}\text { Tetrabenazine, deutetrabenazine valbe- } \\
\text { nazine }\end{array}$ & $\begin{array}{l}\text { Good response } \\
\text { to tetrabenazine }\end{array}$ \\
\hline & $\begin{array}{l}\text { Neuroleptic ma- } \\
\text { lignant syndrome } \\
{[21]}\end{array}$ & $\begin{array}{l}\text { Acute onset stereotypies started with } \\
\text { other manifestations of NMS after one } \\
\text { month of starting risperidone and resol- } \\
\text { ved within } 15 \text { days as patient improved } \\
\text { with treatment of NMS }\end{array}$ & $\begin{array}{l}\text { Conservative treatment for NMS and } \\
\text { bromocriptine }\end{array}$ & $\begin{array}{l}\text { Stereotypies } \\
\text { disappeared } \\
\text { as patient } \\
\text { improved with } \\
\text { treatment }\end{array}$ \\
\hline & $\begin{array}{l}\text { Punding induced } \\
\text { by cocaine and } \\
\text { amphetamine } \\
\text { abuse [22-25] }\end{array}$ & $\begin{array}{l}\text { Delayed onset stereotypies started after } \\
\text { variable time interval from starting drug } \\
\text { abuse and were persistent }\end{array}$ & SSRIS & $\begin{array}{l}\text { No improve- } \\
\text { ment }\end{array}$ \\
\hline & $\begin{array}{l}\text { Levodopa induced } \\
\text { punding and dy- } \\
\text { skinesias [26-29] }\end{array}$ & $\begin{array}{l}\text { Delayed onset stereotypies started 6-22 } \\
\text { years after using levodopa for PD }\end{array}$ & $\begin{array}{l}\text { Decrease in dose of levodopa and dopa } \\
\text { agonist and addition of amantadine and } \\
\text { atypical antipsychotics e.g. clozapine }\end{array}$ & Improvement \\
\hline \multirow[t]{6}{*}{$\begin{array}{l}\text { Stereotypies } \\
\text { in psychiatric } \\
\text { illness }\end{array}$} & $\begin{array}{l}\text { Functional stereo- } \\
\text { typies [35] }\end{array}$ & $\begin{array}{l}\text { Sudden onset stereotypies with variable } \\
\text { clinical course and phenomenology asso- } \\
\text { ciated with distractibility }\end{array}$ & & \\
\hline & $\begin{array}{l}\text { Repetitive beha- } \\
\text { viour in schizop- } \\
\text { hrenia [36] }\end{array}$ & $\begin{array}{l}\text { Delayed onset and persistent, started after } \\
16.7 \pm 6.7 \text { years of disease }\end{array}$ & $\begin{array}{l}\text { Management of complications as a result } \\
\text { of repetitive behaviour such as polydipsia } \\
\text { or bulimia }\end{array}$ & \\
\hline & Psychosis [38] & $\begin{array}{l}\text { Delayed onset and persistent. Started 1-2 } \\
\text { years after onset of psychosis }\end{array}$ & & \\
\hline & $\begin{array}{l}\text { Bipolar disorder } \\
\text { (in the form of } \\
\text { punding) [43] }\end{array}$ & $\begin{array}{l}\text { Delayed onset and persistent. Started } 36 \\
\text { years after disease onset }\end{array}$ & $\begin{array}{l}\text { Quitiapine, clotiapine, alprazolam, sodium } \\
\text { valproate }\end{array}$ & $\begin{array}{l}\text { No improve- } \\
\text { ment }\end{array}$ \\
\hline & $\begin{array}{l}\text { Trichotillomania, } \\
\text { pathological skin } \\
\text { picking, compul- } \\
\text { sive hoarding } \\
\text { [39-42] }\end{array}$ & $\begin{array}{l}\text { Subacute to delayed onset associated } \\
\text { with other symptoms of OCD. Improved } \\
\text { with SSRIs }\end{array}$ & Clomipramine & Improvement \\
\hline & PNES $[44,45]$ & $\begin{array}{l}\text { Acute onset and present only during } \\
\text { episodes of PNES }\end{array}$ & & \\
\hline $\begin{array}{l}\text { Stereotypies } \\
\text { in dementia }\end{array}$ & $\begin{array}{l}\text { FTD (most com- } \\
\text { mon) }[46,47,49 \\
51-58]\end{array}$ & $\begin{array}{l}\text { Delayed onset, progressive and started } \\
6-24 \text { months after disease onset }\end{array}$ & $\begin{array}{l}\text { SSRIs like sertraline and fluvoxamine, } \\
\text { tetrabenazine }\end{array}$ & $\begin{array}{l}\text { Improvement } \\
\text { in stereotypies } \\
\text { and repetitive } \\
\text { behaviour in } \\
\text { patients with } \\
\text { dementia }\end{array}$ \\
\hline
\end{tabular}


Table 2 cont. Clinical characteristics of stereotypies in adults reported in literature

\begin{tabular}{|c|c|c|c|c|}
\hline \multicolumn{2}{|c|}{ Aetiology of stereotypies } & Onset and course of stereotypies & Treatment given & Outcome \\
\hline \multicolumn{2}{|l|}{$\begin{array}{l}\text { Stereotypies } \\
\text { in stroke } \\
{[63-70]}\end{array}$} & $\begin{array}{l}\text { Acute onset started a variable period (a } \\
\text { few days up to one year) after stroke. } \\
\text { Usually resolved spontaneously within } \\
\text { a few months }\end{array}$ & $\begin{array}{l}\text { Benzodiazepine, } \\
\text { sertraline, clonidine, } \\
\text { baclofen }\end{array}$ & $\begin{array}{l}\text { Good response } \\
\text { to clonazepam. } \\
\text { One case } \\
\text { of punding } \\
\text { responded to } \\
\text { sertraline }\end{array}$ \\
\hline $\begin{array}{l}\text { Stereotypies } \\
\text { in autoimmu- } \\
\text { ne disorders }\end{array}$ & $\begin{array}{l}\text { Anti-NMDA recep- } \\
\text { tor encephalitis } \\
{[71-73,74]}\end{array}$ & $\begin{array}{l}\text { Acute onset associated with other clinical } \\
\text { manifestations. Responded to immunosu- } \\
\text { ppressive therapy }\end{array}$ & Immunomodulatory therapy & Good response \\
\hline \multirow[t]{2}{*}{$\begin{array}{l}\text { Stereotypies } \\
\text { in viral encep- } \\
\text { halitis }\end{array}$} & $\begin{array}{l}\text { Herpes simplex } \\
\text { encephalitis [77] }\end{array}$ & $\begin{array}{l}\text { Acute onset started on second day of } \\
\text { illness and persisted for one month }\end{array}$ & $\begin{array}{l}\text { Carbamezapine, } \\
\text { haloperidol }\end{array}$ & $\begin{array}{l}\text { No improve- } \\
\text { ment }\end{array}$ \\
\hline & $\begin{array}{l}\text { Encephalitis lethar- } \\
\text { gica }[78,79]\end{array}$ & $\begin{array}{l}\text { Subacute onset and improved with dopa- } \\
\text { minergic therapy within } 1-2 \text { months }\end{array}$ & Levodopa, dopa agonist & Improvement \\
\hline
\end{tabular}

NMS - neuroleptic malignant syndrome; PNES — psychogenic non epileptic seizures; FTD — frontotemporal dementia; PD — Parkinson's Disease; OCD — Obsessive Compulsive Disorder; SSRI — selective serotonin reuptake inhibitor; NMDA - N-methyl-D-aspartate; GABA — gamma aminobutyric acid

for years, but deutetrabenazine and valbenazine have been recently approved by the US FDA. Compared to tetrabenazine, deutetrabenazine and valbenazine have longer plasma half-life, require less frequent dosing, and produce fewer side effects, making them first line agents [18-20]. Other drugs that have been used in the treatment of TD with inconsistent benefits are clonazepam, baclofen, amantadine, and gingko biloba extract. However, none of these drugs have been approved by the FDA for the treatment of tardive dyskinesia or tardive stereotypy $[18,19]$.

Apart from tardive dyskinesia or tardive stereotypy, neuroleptics can also cause neuroleptic malignant syndrome (NMS) which is an idiosyncratic reaction characterised by a tetrad of fever, rigidity, altered mental status, and autonomic dysfunction. NMS can feature various hypokinetic and hyperkinetic movements such as rigidity, tremors, dystonia, and chorea, although stereotypy has been reported in only one case [21].

Another example of drug induced stereotypic movements is 'punding', a Swedish word meaning 'blockhead'. This was first described by Rylander in amphetamine and cocaine addicts [22]. Punding is a stereotyped behaviour characterised by an intense fascination with a complex, excessive, non-goal oriented, repetitive activity such as manipulation of technical equipment, handling, examining or sorting common objects, grooming, hoarding or engaging in extended monologues devoid of content. Men tend to repetitively tinker with equipment such as radios, clocks, watches, and engines, the parts of which may be analysed, arranged, sorted, and catalogued but are rarely put back together. Women, in contrast, incessantly sort through their handbags, tidy continuously, brush their hair, or polish their nails $[23,24]$. This is the most severe form of repetitive reward-seeking behaviour syndrome [25].

Punders are aware of their abnormal repetitive behaviour, but they find it soothing and calming and become agitated if distracted. Although punding was first described in people using central nervous system stimulants like amphetamine and cocaine, now it is frequently seen in patients with Parkinson's Disease (PD) treated with dopamine replacement therapy (levodopa, apomorphine, and dopa agonists) [24-28] Levodopa-induced punding and stereotypies in PD patients can be treated by reducing the dose of levodopa and dopa agonists, and adding amantadine or clozapine which are anti-dyskinetic agents [29]. For patients with severe disabling dyskinesias, DBS surgery of the subthalamic nucleus or GPi can be carried out [29].

Other drugs causing punding and stereotypic movements are morphine, disulfiram, bupropion, methylphenidate, and anticholinergics like benztropine [30-34].

\section{Stereotypies in psychiatric disorders}

Stereotypies have been reported in many patients with psychiatric illnesses. Also, patients of functional movement disorder (FMD) can have stereotypic movements referred to as functional stereotypy (FS). In the study by Jankovic and Baizabal-Carvallo on 184 patients with FMD, it was observed that $19(10.3 \%)$ patients had FS [35]. The clinical characteristics of movements in these patients were compared to those of 65 patients of tardive dyskinesia. Functional stereotypies were more common in young females and involved the orolingual regions, the limbs, trunk, and respiratory muscles. Compared to TD, patients with FS had a lower frequency of exposure to neuroleptics, had a sudden onset of symptoms, distractibility on examination, and periods of unexplained improvement. Also, patients with functional orolingual stereotypies had pure lingual movements without mouth involvement, abnormal speech, chewing movements or tongue biting [35].

Repetitive behaviours have been described in schizophrenics apart from other symptoms of the disease [36, 37]. A study was done in 32 chronically institutionalised schizophrenia patients [36]. Fifteen (47\%) displayed at least one severe, or two moderate, repetitive behaviours. The total score of repetitive behaviours was significantly correlated with positive symptoms 
rather than negative symptoms of schizophrenia. Also, it was observed that repetitive behaviours were more common the longer the hospital stay, suggesting the influence of environmental factors (chronic hospitalisation) on the occurrence of repetitive behaviours in schizophrenics.

Compton et al. published a study on abnormal movements in patients presenting with a first episode of psychosis with minimal antipsychotic exposure. They measured stereotypies, dyskinesias, and catatonia-like signs. The stereotypies scores were significantly correlated with age at onset of psychosis and with positive symptom severity score [38].

Other psychiatric disorders with repetitive behaviours are compulsive hoarding, trichotillomania or hair disorder, and pathological skin picking [39-43]. These patients respond to selective serotonin reuptake inhibitors (SSRIs) like sertraline, fluvoxamine and tricyclic antidepressants like clomipramine [42] .

Stereotypies have also been reported in patients of psychogenic non-epileptic seizures (PNES). Seneviratne et al. studied different semiologies of ictal events in patients of PNES [44]. The rhythmic motor PNES had rhythmic stereotypic trembling movements of extremities and trunk in a symmetrical and synchronised manner, with more common involvement of upper limbs than of lower limbs. Also, $10 \%$ of patients had vocalisations and hyperventilation in addition to rhythmic movements. In another study by Herskovitz on 29 patients with PNES, it was observed that stereotypic behaviour and motor manifestations of PNES in an individual patient were consistent in all seizures, although the duration of episodes of PNES was inconsistent [45].

\section{Stereotypies in dementia}

Stereotypic behaviours and stereotypies (motor and phonic) have been described in all types of degenerative dementias with variable frequency [46-49]. In patients with behavioural variant of frontotemporal dementia (bvFTD), the presence of stereotypies indeed forms a supporting criterion for the diagnosis [50]. In a large multicentre observational study, Prioni et al. reported the type, frequency, and severity of stereotypies in different types of degenerative dementias, i.e. bvFTD, Alzheimer's Disease (AD), Parkinson's Disease Dementia (PDD) and progressive supranuclear palsy (PSP). It was observed that stereotypies were present with variable frequency in all types of degenerative dementias, but they were most frequent in bvFTD (86\%) and PDD (88.6\%), and least frequent in $\mathrm{AD}(57.8 \%)$ [51]. They also assessed stereotypies in these patients using a five domain 'stereotypy rating inventory'. It was observed that multidomain stereotypies were more frequent in bvFTD $(80 \%)$ patients than in others. Also, the stereotypies were more severe in bvFTD patients. All patients had a high frequency of movement stereotypies, while eating, cooking and speaking stereotypies were most frequent in bvFTD patients. The presence of stereotypies in these patients was directly related to neuropsychiatric dysfunction and cognitive impairment, and inversely related to motor impairment [51].
In another study, Prioni et al. compared stereotypies in 53 patients with bvFTD and 40 patients with the Richardson variant of PSP (PSP-RS) [52]. In total, stereotypies were present in at least one domain in $81 \%$ of bvFTD and in $57.5 \%$ of PSPRS patients, and multi-domain in 79\% of bvFTD and $40 \%$ of PSP-RS patients, indicating a higher frequency of stereotypies in bvFTD compared to PSP-RS. Also, complex stereotypies and stereotypies in the cooking/eating domain were more common in patients with bvFTD. But a much greater proportion of PSP-RS patients (69.5\%) than of bvFTD patients (20\%) had awareness of their stereotypies. It was initially thought that stereotypies in PSP patients were levodopa-induced. However, these were present in both 'off' and 'on' states, suggesting that they were not in fact drug-induced but rather occurred as a part of the disease spectrum.

Another study demonstrated that simple motor stereotypies were common in all types of degenerative dementias, although complex motor stereotypies and repetitive behaviours were more commonly associated with bvFTD [53]. Mateen and Joseph studied the clinical spectrum of stereotypies in 32 patients of frontotemporal lobar degeneration (FTLD). 19 (60\%) patients had stereotypies, with the majority $(68 \%)$ being female [54]. Only motor stereotypies were present in 13 patients, only vocal stereotypies were present in three patients, and both vocal and motor stereotypies were present in three patients. In patients with only motor stereotypies, nine had appendicular and seven had craniocervical stereotypies. In another study, Nyatsanza et al. reported a higher prevalence of complex stereotypies and stereotypic behaviours in patients with bvFTD than in patients with AD [55].

There have been various radiological studies designed to understand the anatomical correlate of stereotypies in degenerative dementia. In one study, voxel-based morphometric magnetic resonance imaging (MRI) was performed to understand the anatomical correlate of stereotypies in FTD. It was observed that patients with stereotypy had greater striatal to cortical loss compared to patients with no stereotypies, suggesting that striatal degeneration is a pathophysiological correlate of stereotypies [56]. A similar functional imaging study using single-photon emission computed tomography (SPECT) determined that patients with simple stereotypies have greater involvement of the right frontal lobe and patients with complex stereotypies have greater involvement of the left temporal lobe [57]. Also, it has been suggested that complex stereotypies arise from dysfunction of the orbitofrontal and temporal cortex and its subcortical connections, while simple stereotypies arise from dysfunction of the dorsolateral frontal cortex and its subcortical connections [53].

Stereotypies and stereotypic behaviours in patients with FTD usually do not respond well to antidepressants and other medications, although tetrabenazine showed some benefit in a case series of seven patients with probable FTD [58]. 


\section{Stereotypies in stroke}

Stroke (both ischaemic and haemorrhagic) is known to cause a variety of abnormal involuntary movement disorders, but stereotypies have rarely been reported [59-60]. In the Lausanne Stroke Registry, out of 2,500 stroke patients, only 29 (1\%) developed post-stroke hyperkinetic abnormal movements, and only two $(2 / 29 ; 7 \%)$ patients developed stereotypies [61]. In another study of 1,500 stroke patients by Alarcon et al., 56 patients developed post stroke movement disorders, but none of them had stereotypies [62].

Stereotypies result from an infarct in the region of parietal, lenticulo-striatal, thalamic, midbrain or left middle cerebral artery territory causing dysfunction of basal ganglia, thalamus, brainstem and cerebellum [60]. These are usually unilateral and contralateral to the side of the lesion [63]. However, bilateral stereotypic movements have also been described [64]. In cases of cerebellar infarcts, stereotypies are unilateral and ipsilateral to the side of the lesion [65]. It is observed that right-sided lesions are more prone to produce stereotypies than left-sided lesions. Post-stroke stereotypies can be simple, for example continuous tapping of the contralateral hand secondary to unilateral thalamic infarct, or complex, like repeated pirouetting while walking or repeated ritualistic movements like hand clapping, flailing arms, whispering, protruding the tongue, sniffing before performing any voluntary movement secondary to right putaminal infarct [64]. Ipsilateral instinctive grasp and stereotyped involuntary movements like groping or picking is described with right frontal lobe infarction [66]. Complex stereotypies like punding and palilalia (repetition of one's own syllables, words, or phrases two or more times in a row) are also described secondary to pontine, thalamic and midbrain infarcts $[67,68]$.

A patient with locked-in syndrome with infarct in ventral pons has been described who developed synchronous involuntary movements of the soft palate with movements of tongue one-year post-stroke and involuntary chewing, pouting movements and bruxism several months later [69]. Stereotypies usually develop a few days to a few weeks after an acute infarct, and decrease over a few months up to a year. The exact pathophysiology for developing stereotypic movements in stroke patients is still unclear. They are probably caused by the disruption of cortico-striatal-thalamo-cortical and cerebellothalamic pathways which are required to inhibit involuntary movements while performing voluntary actions. Disruption of these pathways can give rise to abnormal involuntary movements including stereotypies. Some stroke patients may have cognitive dysfunction and abnormal behaviour, and stereotypies are usually an accompanying feature of it $[64,65]$. Various drugs like benzodiazepines, anticholinergics, amantadine, and dopamine antagonists have been tried in post-stroke stereotypies, but none have provided any significant benefit [64]. Only a few cases of simple stereotypy benefited from clonazepam, and some cases responded to sertraline $[67,70]$. However, post-stroke stereotypic movements usually decrease and sometimes resolve spontaneously over time [68].

\section{Stereotypies in autoimmune encephalitis}

Autoimmune encephalitis can present with a wide spectrum of movement disorders including stereotypy [71-73, 74]. But most of the studies reporting stereotypy in autoimmune encephalitis patients are from paediatric populations. Overall, stereotypy is more commonly seen in anti-N-methyl-D-aspartate receptor (NMDAR) encephalitis patients. Mohammad et al. studied abnormal movements in children with a diagnosis of anti-NMDAR encephalitis, autoimmune basal ganglia encephalitis, and Sydenham's Chorea [71]. Stereotypies and perseverations were present exclusively in patients of anti-NMDAR encephalitis, while tremor and akinesia were more common in basal ganglia encephalitis. Granata et al. studied 18 patients of anti-NMDAR encephalitis of paediatric age [72]. All had stereotypic movements along with other movements. In eight patients, abnormal stereotypic movements persisted during sleep. Three patients presented with movement disorder as the initial manifestation. Stereotypies were the most characteristic movements and were present in all patients. Both simple and complex stereotypies were noted. Simple stereotypies included cycling leg movements, thrashing of limbs, repetitive flexion-extension of the trunk, 'yes-yes', and 'no-no' head movements, while complex stereotypies included raising and lowering of the arms, movements which aimlessly produced learned movements such as playing the piano or dance steps. Another type of stereotypic movement observed was perseverations. These are repetitive and persistent motor tasks or vocalisations triggered by a voluntary activity or stimulus. Simple stereotypies were more common in $<12$ years of age group, while complex stereotypies were more common in teenagers [72]. Dash et al. studied the spectrum of movement disorder in adolescents and adults with non-neoplastic autoimmune encephalitis [73]. Out of a total of 362 patients screened, 41 were positive for autoantibodies and 21 (51.2\%) of the 41 had movement disorders. Stereotypies were present in only three patients (14.2\%) and all were positive for anti-NMDAR antibodies. Dash et al. also noted that only $12.5 \%$ of anti-NMDAR positive patients had stereotypies and all of them were $<18$ years of age, suggesting that stereotypies are more common in children with anti-NMDAR encephalitis than in adults. Baizabal-Carvallo et al. have described abnormal involuntary movements in nine children with anti-NMDA receptor encephalitis aged 3 to 14 [74]. Although stereotypies are described more commonly in anti-NMDAR encephalitis, there is one case report with adult-onset motor stereotypies with anti-basal ganglia antibody positive encephalitis [75].

The exact pathophysiology of stereotypical movements in anti-NMDAR encephalitis is not known, but as suggested there is possible antibody mediated internalisation of NMDA receptors in striatum and brainstem and antibody mediated dysfunction of basal ganglia-cortical connections leading to loss of fronto-striatal inhibition causing abnormal stereotypic movements and perseverations [71,72]. These movements are more common in paediatric patients than in adults because 
of age-related changes in dopamine receptor sensitivity and regional distribution, making children more sensitive to develop stereotypies than adults [72]. Similar to the other clinical features of autoimmune encephalitis, stereotypies are also responsive to immunomodulatory therapy in the form of methylprednisolone, intravenous immunoglobulin, rituximab and cyclophosphamide [76].

\section{Stereotypies in viral encephalitis}

Viral encephalitis is known to cause various hypokinetic and hyperkinetic abnormal movements as a result of frequent involvement of the thalamus, basal ganglia, substantia nigra, and brainstem. However stereotypic movements have been reported in only one case of post viral encephalitis [77]. A 34-year-old woman diagnosed with herpes simplex encephalitis with bilateral temporal lobe involvement developed motor stereotypy and hypersexual behaviour after regaining consciousness. She had repetitive, involuntary movements of the right arm, with scratching causing abrasions on the right side of her face. At one-month follow up she was still having these stereotypic movements which were interfering with daily routine activities such as applying makeup, washing and dressing, and these movements did not respond to carbamazepine and haloperidol. This case was proposed to be a partial form of Kluver-Bucy syndrome with involvement of bilateral temporal lobes and stereotypic movements occurring as a result of disruption of dopaminergic transmission in basal ganglia, medial temporal lobe, amygdala and hippocampus.

Another infectious encephalitis associated with stereotypical movements is 'encephalitis lethargica', but its causative agent has not been determined to date. Encephalitis lethargica is associated with complex stereotypical movements along with other clinical features like dystonia, parkinsonism, irritability, psychiatric behaviour, agitation, oculogyric crisis, and autonomic instability. Stereotypies occur more often in the upper limbs in the form of gripping both hands, placing hands on the waist, combing hands through hair, and fiddling with a nasogastric tube $[78,79]$. All abnormal movements i.e. parkinsonism, dystonia, and stereotypy respond to dopaminergic drugs (levodopa and D2 agonists) while they do not show any improvement with other classes of drugs. This suggests that these abnormal movements result from limited disruption of dopaminergic neurons in the substantia nigra pars compacta acting via D2 receptors causing a dopaminergic deficiency in the striatum [79].

\section{Differential diagnosis of stereotypies in adults}

In adults, stereotypies need to be differentiated from other repetitive movement disorders such as tics, mannerisms, compulsions and habits. Among these, stereotypies are most frequently confused with tics [3]. Tics are sudden, brief, rapid, recurrent, nonrhythmic motor movements or vocalisations, while stereotypies are rhythmic, repetitive movements occurring in a loop [3]. Often, multiple types of tics when occurring in a burst can be confused with stereotypies. But in a tic disorder, there is a non-random occurrence of the same type of tic movement after some time, which is not repetitive as in stereotypies. Also, tics are associated with premonitory urge and are highly variable, with changing patterns and severity as they evolve [3].

Although tics and Tourette's Syndrome are childhood onset disorders, and are more common in children, they are not uncommon in adults. Jankovic has studied the characteristics of Tourette's Syndrome in adults [80]. He compared 43 adult Tourette's patients to 100 paediatric patients. Among the 43 adults, 35 (81.4\%) had their tic onset before the age of 18 , with either re-emergence or exacerbation of childhood onset TS in adulthood. Only eight $(18.6 \%)$ patients had onset after the age of 18 , with two $(4.4 \%)$ patients reporting their first tic after the age of 50. Adult patients with TS had more facial and truncal tics, fewer phonic tics, and more frequently suffered from substance abuse and mood disorders compared to children [80]. Different types of tics can be seen in TS patients, including clonic tics, tonic tics and dystonic tics. Dystonic tics are slower and last longer compared to clonic tics, causing a sustained, but not fixed, posture [81]. When dystonic tics occur in succession, they can be confused with stereotypies because of apparent rhythmicity. Self-harming behaviour is also common in TS patients because of either malignant tics or psychiatric comorbidities [82]. Such behaviours should be differentiated from the self-harming behaviours of stereotypic movement disorders. Patients with TS can be treated by behavioural therapy or pharmacotherapy. Antidopaminergic drugs like dopamine receptor blockers and dopamine depletors are used. Recently, aripiprazole has been approved by the FDA for the treatment of TS. It has a similar efficacy and a favourable side effect profile compared to other neuroleptics [83].

\section{Conclusion}

Although stereotypic movements are more commonly described in children, they are frequently seen in adults, but often go unidentified. Both physiological and pathological stereotypies are common in adults. Many neuropsychiatric conditions can result in adult-onset stereotypic movements secondary to dysfunction of cortico-striatal-thalamo-cortical pathways and loss of frontal-striatal inhibition. In fact, stereotypic movements form one of the supporting criteria for the diagnosis of bvFTD. Also, stereotypic movements in adults are frequently accompanied by cognitive decline, behavioural disturbance, and other hypokinetic and hyperkinetic movement disorders. Children with stereotypies can be treated by behavioural therapy alone, but adults usually require pharmacotherapy and treatment of the underlying neuropsychiatric conditions. 
So, stereotypies in adults are not as uncommon as has been thought. It is important to recognise these abnormal movements because they give a clue to the underlying diagnosis.

Roles of authors: Dr. Shukla contributed to data collection and manuscript preparation. Dr. Pandey contributed to manuscript preparation, review and critique.

Funding / Conflict of interest: None.

\section{References:}

1. Edwards MJ, Lang AE, Bhatia KP. Stereotypies: a critical appraisal and suggestion of a clinically useful definition. Mov Disord. 2012; 27(2): 179-185, doi: 10.1002/mds.23994, indexed in Pubmed: 22161914.

2. Katherine M. Stereotypic Movement Disorders. Semin Pediatr Neurol. 2018; 25: 19-24, doi: 10.1016/j.spen.2017.12.004, indexed in Pubmed: 29735112.

3. Singer HS. Motor stereotypies. Semin Pediatr Neurol. 2009; 16(2): 77-81, doi: 10.1016/j.spen.2009.03.008, indexed in Pubmed: 19501335.

4. Maltête D. Adult-onset stereotypical motor behaviors. Rev Neurol (Paris). 2016; 172(8-9): 477-482, doi: 10.1016/j.neurol.2016.07.002, indexed in Pubmed: 27498241.

5. Muthugovindan D, Singer H. Motor stereotypy disorders. Curr Opin Neurol. 2009; 22(2): 131-136, doi: 10.1097/WC0.0b013e328326f6c8, indexed in Pubmed: 19532036.

6. Harris KM, Mahone EM, Singer HS. Nonautistic motor stereotypies: clinical features and longitudinal follow-up. Pediatr Neurol. 2008; 38(4): 267-272, doi: 10.1016/j.pediatrneurol.2007.12.008, indexed in Pubmed: 18358406.

7. Oakley C, Mahone EM, Morris-Berry C, et al. Primary complex motor stereotypies in older children and adolescents: clinical features and longitudinal follow-up. Pediatr Neurol. 2015; 52(4): 398-403. e1, doi: 10.1016/j.pediatrneurol.2014.11.002, indexed in Pubmed: 25661287.

8. Freeman RD, Soltanifar A, Baer S. Stereotypic movement disorder: easily missed. Dev Med Child Neurol. 2010; 52(8): 733-738, doi: 10.1111/j.1469-8749.2010.03627.x, indexed in Pubmed: 20187883.

9. Jankovic J. Leg stereotypy disorder. J Neurol Neurosurg Psychiatry. 2016 Feb 1. ; 87(2): 220-1.

10. Niehaus DJ, Emsley RA, Brink P, et al. Stereotypies: prevalence and association with compulsive and impulsive symptoms in college students. Psychopathology. 2000; 33(1): 31-35, doi: 10.1159/000029116, indexed in Pubmed: 10601825.

11. Sarkhel S, Praharaj SK, Akhtar S. Cheek-biting disorder: another stereotypic movement disorder? J Anxiety Disord. 2011; 25(8): 10851086, doi: 10.1016/j.janxdis.2011.07.006, indexed in Pubmed: 21889295 .

12. Chisholm T, Morehouse RL. Adult headbanging: sleep studies and treatment. Sleep. 1996; 19(4): 343-346, doi: 10.1093/ sleep/19.4.343, indexed in Pubmed: 8776793.

13. Alves RS, Alóe F, Silva AB, et al. Jactatio capitis nocturna with persistence in adulthood. Case report. Arq Neuropsiquiatr. 1998; 56(3B): 655-657, doi: 10.1590/s0004-282x1998000400022, indexed in Pubmed: 9850765.

14. Vijayakumar D, Jankovic J. Drug-Induced Dyskinesia, Part 2: Treatment of Tardive Dyskinesia. Drugs. 2016; 76(7): 779-787, doi: 10.1007/ s40265-016-0568-1, indexed in Pubmed: 27091214.
15. Peña MS, Yaltho TC, Jankovic J. Tardive dyskinesia and other movement disorders secondary to aripiprazole. Mov Disord. 2011; 26(1): 147-152, doi: 10.1002/mds.23402, indexed in Pubmed: 20818603.

16. Kaneko K, Yuasa T, Miyatake T, et al. Stereotyped hand clasping: an unusual tardive movement disorder. Mov Disord. 1993; 8(2): $230-$ 231, doi: 10.1002/mds.870080224, indexed in Pubmed: 8474498.

17. Madruga-Garrido M, Mir P. Tics and other stereotyped movements as side effects of pharmacological treatment. Int Rev Neurobiol. 2013; 112: 481-494, doi: 10.1016/B978-0-12-411546-0.00016-0, indexed in Pubmed: 24295631.

18. Margolius A, Fernandez HH. Current treatment of tardive dyskinesia. Parkinsonism Relat Disord. 2019; 59: 155-160, doi: 10.1016/j. parkreldis.2018.12.022, indexed in Pubmed: 30591350.

19. Niemann N, Jankovic J. Treatment of Tardive Dyskinesia: A General Overview with Focus on the Vesicular Monoamine Transporter 2 Inhibitors. Drugs. 2018; 78(5): 525-541, doi: 10.1007/s40265-0180874-x, indexed in Pubmed: 29484607.

20. Scorr LM, Factor SA. VMAT2 inhibitors for the treatment of tardive dyskinesia. J Neurol Sci. 2018; 389: 43-47, doi: 10.1016/j. jns.2018.02.006, indexed in Pubmed: 29433808.

21. Pandey S, Shukla T. Stereotypy in Neuroleptic Malignant Syndrome. Movement Disorders Clinical Practice. 2019; 6(5): 411-412, doi: 10.1002/mdc3.12770.

22. Rylander G. Psychoses and the punding and choreiform syndromes in addiction to central stimulant drugs. Psychiatr Neurol Neurochir. 1972; 75(3): 203-212, indexed in Pubmed: 4625014.

23. Rusyniak DE. Neurologic manifestations of chronic methamphetamine abuse. Psychiatr Clin North Am. 2013; 36(2): 261-275, doi: 10.1016/j.psc.2013.02.005, indexed in Pubmed: 23688691.

24. Fasano A, Petrovic I. Insights into pathophysiology of punding reveal possible treatment strategies. Mol Psychiatry. 2010; 15(6): 560-573, doi: 10.1038/mp.2009.95, indexed in Pubmed: 20489735.

25. Fasano A, Barra A, Nicosia P, et al. Cocaine addiction: from habits to stereotypical-repetitive behaviors and punding. Drug Alcohol Depend. 2008; 96(1-2): 178-182, doi: 10.1016/j.drugalcdep.2008.02.005, indexed in Pubmed: 18378407.

26. Spencer AH, Rickards H, Fasano A, et al. The prevalence and clinical characteristics of punding in Parkinson's disease. Mov Disord. 2011; 26(4): 578-586, doi: 10.1002/mds.23508, indexed in Pubmed: 21648123.

27. Silveira-Moriyama L, Evans A, Katzenschlager R, et al. Punding and dyskinesias. Movement Disorders. 2006; 21(12): 2214-2217, doi: 10.1002/mds.21118.

28. Lawrence AJ, Blackwell AD, Barker RA, et al. Predictors of punding in Parkinson's disease: results from a questionnaire survey. Mov Disord. 2007; 22(16): 2339-2345, doi: 10.1002/mds.21702, indexed in Pubmed: 17914729.

29. Vijayakumar D, Jankovic J. Drug-Induced Dyskinesia, Part 1: Treatment of Levodopa-Induced Dyskinesia. Drugs. 2016; 76(7): 759-777, doi: 10.1007/s40265-016-0566-3, indexed in Pubmed: 27091215.

30. Fan CC, Lin SKu, Huang MC. Disulfiram-induced punding. J Clin Psychopharmacol. 2008; 28(4): 473-474, doi: 10.1097/ JCP.0b013e31817d8702, indexed in Pubmed: 18626287.

31. Kornetsky C. Brain-stimulation reward, morphine-induced oral stereotypy, and sensitization: implications for abuse. Neurosci Biobehav Rev. 2004; 27(8): 777-786, doi: 10.1016/j.neubiorev.2003.11.014, indexed in Pubmed: 15019427.

32. Jacobsen LK, Chappell P, Woolston JL. Bupropion and compulsive behavior. J Am Acad Child Adolesc Psychiatry. 1994; 33(1): 143-144, 
doi: 10.1097/00004583-199401000-00023, indexed in Pubmed: 8138514.

33. Costall B, Naylor RJ. The involvement of dopaminergic systems with the stereotyped behaviour patterns induced by methylphenidate. J Pharm Pharmacol. 1974; 26(1): 30-33, doi: 10.1111/j.20427158.1974.tb12815.x, indexed in Pubmed: 4150931.

34. Kulik AV, Wilbur R. Delirium and stereotypy from anticholinergic antiparkinson drugs. Progress in Neuro-Psychopharmacology and Biological Psychiatry. 1982; 6(1): 75-82, doi: 10.1016/s03647722(82)80110-0.

35. Baizabal-Carvallo JF, Jankovic J. Functional (psychogenic) stereotypies. J Neurol. 2017; 264(7): 1482-1487, doi: 10.1007/s00415-0178551-7, indexed in Pubmed: 28653211.

36. Luchins DJ, Goldman MB, Lieb M, et al. Repetitive behaviors in chronically institutionalized schizophrenic patients. Schizophr Res. 1992; 8(2): 119-123, doi: 10.1016/0920-9964(92)90027-3, indexed in Pubmed: 1457389.

37. Daniels JE, Wirth JB, Herrera DG, et al. Head banging on an inpatient psychiatric unit: a vicious circle. Harv Rev Psychiatry. 2007; 15(2): 70-79, doi: 10.1080/10673220701307588, indexed in Pubmed: 17454176.

38. Compton MT, Fantes F, Wan CR, et al. Abnormal movements in first-episode, nonaffective psychosis: dyskinesias, stereotypies, and catatonic-like signs. Psychiatry Res. 2015; 226(1): 192-197, doi: 10.1016/j. psychres.2014.12.048, indexed in Pubmed: 25619434.

39. Stein DJ, Grant JE, Franklin ME, et al. Trichotillomania (hair pulling disorder), skin picking disorder, and stereotypic movement disorder: toward DSM-V. Depress Anxiety. 2010; 27(6): 611-626, doi: 10.1002/ da.20700, indexed in Pubmed: 20533371.

40. Odlaug BL, Grant JE. Clinical characteristics and medical complications of pathologic skin picking. Gen Hosp Psychiatry. 2008; 30(1): 61-66, doi: 10.1016/j.genhosppsych.2007.07.009, indexed in Pubmed: 18164942.

41. Pertusa A, Fullana MA, Singh $S$, et al. Compulsive hoarding: $O C D$ symptom, distinct clinical syndrome, or both? Am J Psychiatry. 2008; 165(10): 1289-1298, doi: 10.1176/appi.ajp.2008.07111730, indexed in Pubmed: 18483134.

42. Sani G, Gualtieri I, Paolini M, et al. Drug Treatment of Trichotillomania (Hair-Pulling Disorder), Excoriation (Skin-picking) Disorder, and Nail-biting (Onychophagia). Curr Neuropharmacol. 2019; 17(8): 775-786, doi: 10.2174/1570159X17666190320164223, indexed in Pubmed: 30892151.

43. Pettorruso M, Di Nicola M, De Risio L, et al. Punding behavior in bipolar disorder type 1: case report. J Neuropsychiatry Clin Neurosci. 2014; 26(4): E8-E9, doi: 10.1176/appi.neuropsych.13090217, indexed in Pubmed: 26037886.

44. Seneviratne U, Reutens D, D'Souza W. Stereotypy of psychogenic nonepileptic seizures: insights from video-EEG monitoring. Epilepsia. 2010; 51(7): 1159-1168, doi: 10.1111/j.1528-1167.2010.02560.x, indexed in Pubmed: 20384722.

45. Herskovitz M. Stereotypy of psychogenic nonepileptic seizures. Epilepsy Behav. 2017; 70(Pt A): 140-144, doi: 10.1016/j.yebeh.2017.02.015, indexed in Pubmed: 28427022.

46. Cipriani G, Vedovello M, Ulivi M, et al. Repetitive and stereotypic phenomena and dementia. Am J Alzheimers Dis Other Demen. 2013; 28(3): 223-227, doi: 10.1177/1533317513481094, indexed in Pubmed: 23512997.

47. Ames D, Cummings JL, Wirshing WC, et al. Repetitive and compulsive behavior in frontal lobe degenerations. J Neuropsychiatry Clin Neu- rosci. 1994; 6(2): 100-113, doi: 10.1176/jnp.6.2.100, indexed in Pubmed: 8044031.

48. Kobayashi R, Hayashi H, Tokairin T, et al. Suicide as a result of stereotypic behaviour in a case with semantic dementia. Psychogeriatrics. 2019; 19(1): 80-82, doi: 10.1111/psyg.12357, indexed in Pubmed: 30058742.

49. Hwang JP, Tsai SJ, Yang CH, et al. Repetitive phenomena in dementia. Int J Psychiatry Med. 2000; 30(2): 165-171, doi: 10.2190/2QDAYAL3-2E69-PYJW, indexed in Pubmed: 11001279.

50. Rascovsky K, Hodges JR, Knopman D, et al. Sensitivity of revised diagnostic criteria for the behavioural variant of frontotemporal dementia. Brain. 2011; 134(Pt 9): 2456-2477, doi: 10.1093/brain/awr179, indexed in Pubmed: 21810890.

51. Prioni S, Fetoni V, Barocco F, et al. Stereotypic behaviors in degenerative dementias. J Neurol. 2012; 259(11): 2452-2459, doi: 10.1007/ s00415-012-6528-0, indexed in Pubmed: 22648476.

52. Prioni S, Redaelli V, Soliveri P, et al. Stereotypic behaviours in frontotemporal dementia and progressive supranuclear palsy. Cortex. 2018; 109: 272-278, doi: 10.1016/j.cortex.2018.09.023, indexed in Pubmed: 30399478.

53. Cagnin A, Formentin C, Pompanin S, et al. Simple motor stereotypies are not specific features of behavioural frontotemporal dementia. J Neurol Neurosurg Psychiatry. 2014; 85(8): 945-946, doi: 10.1136/ jnnp-2013-307471, indexed in Pubmed: 24534731.

54. Mateen FJ, Josephs KA. The clinical spectrum of stereotypies in frontotemporal lobar degeneration. Mov Disord. 2009; 24(8): 1237-1240, doi: 10.1002/mds.22555, indexed in Pubmed: 19412926.

55. Nyatsanza S, Shetty T, Gregory C, et al. A study of stereotypic behaviours in Alzheimer's disease and frontal and temporal variant frontotemporal dementia. J Neurol Neurosurg Psychiatry. 2003; 74(10): 1398-1402, doi: 10.1136/jnnp.74.10.1398, indexed in Pubmed: 14570833.

56. Josephs KA, Whitwell JL, Jack CR. Anatomic correlates of stereotypies in frontotemporal lobar degeneration. Neurobiol Aging. 2008; 29(12): 1859-1863, doi: 10.1016/j.neurobiolaging.2007.04.027, indexed in Pubmed: 17574708.

57. McMurtray AM, Chen AK, Shapira JS, et al. Variations in regional SPECT hypoperfusion and clinical features in frontotemporal dementia. Neurology. 2006; 66(4): 517-522, doi: 10.1212/01. wnl.0000197983.39436.e7, indexed in Pubmed: 16505304.

58. Ondo WG. Tetrabenazine treatment for stereotypies and tics associated with dementia. J Neuropsychiatry Clin Neurosci. 2012; 24(2): 208-214, doi: 10.1176/appi.neuropsych.11030077, indexed in Pubmed: 22772669.

59. Defebvre L, Krystkowiak P. Movement disorders and stroke. Rev Neurol (Paris). 2016; 172(8-9): 483-487, doi: 10.1016/j.neurol.2016.07.006, indexed in Pubmed: 27476417.

60. Mehanna R, Jankovic J, Mehanna R, et al. Movement disorders in cerebrovascular disease. Lancet Neurol. 2013; 12(6): 597-608, doi: 10.1016/S1474-4422(13)70057-7, indexed in Pubmed: 23602779.

61. Ghika-Schmid F, Ghika J, Regli F, et al. Hyperkinetic movement disorders during and after acute stroke: the Lausanne Stroke Registry. J Neurol Sci. 1997; 146(2): 109-116, doi: 10.1016/s0022510x(96)00290-0, indexed in Pubmed: 9077506.

62. Alarcón F, Zijlmans JCM, Dueñas G, et al. Post-stroke movement disorders: report of 56 patients. J Neurol Neurosurg Psychiatry. 2004; 75(11): 15681574, doi: 10.1136/jnnp.2003.011874, indexed in Pubmed: 15489389.

63. Pandey S, Sarma N. Stereotypy After Acute Thalamic Infarct. JAMA Neurol. 2015; 72(9): 1068, doi: 10.1001/jamaneurol.2015.0916, indexed in Pubmed: 26167677. 
64. Maraganore DM, Lees AJ, Marsden CD. Complex stereotypies after right putaminal infarction: a case report. Mov Disord. 1991; 6(4): 358-361, doi: 10.1002/mds.870060418, indexed in Pubmed: 1758457.

65. Lee D, Lee D, Ahn TB. Stereotypy after cerebellar infarction. J Neurol Sci. 2014; 344(1-2): 227-228, doi: 10.1016/j.jns.2014.06.019, indexed in Pubmed: 24974238.

66. Inatomi Y, Nakajima M, Yonehara T, et al. Ipsilateral Tremor-Like Grasp Reaction in a Patient With Ischemic Stroke. Cogn Behav Neurol. 2017; 30(1): 37-41, doi: 10.1097/WNN.0000000000000113, indexed in Pubmed: 28323685.

67. Nguyen FN, Pauly RR, Okun MS, et al. Punding as a complication of brain stem stroke?: report of a case. Stroke. 2007; 38(4): 13901392, doi: 10.1161/01.STR.0000260088.07611.6e, indexed in Pubmed: 17332454.

68. Yasuda Y, Akiguchi I, Ino M, et al. Paramedian thalamic and midbrain infarcts associated with palilalia. J Neurol Neurosurg Psychiatry. 1990; 53(9): 797-799, doi: 10.1136/jnnp.53.9.797, indexed in Pubmed: 2246662.

69. Duffey P, Jenkins N, King D. Palatal tremor and orofacial stereotypies within the locked-in syndrome. Mov Disord. 2007; 22(4): 593-595, doi: 10.1002/mds.21327, indexed in Pubmed: 17230478.

70. McGrath CM, Kennedy RE, Hoye W, et al. Stereotypic movement disorder after acquired brain injury. Brain Inj. 2002; 16(5): 447-451, doi: 10.1080/02699050110113660, indexed in Pubmed: 12097226.

71. Mohammad SS, Fung VSC, Grattan-Smith P, et al. Movement disorders in children with anti-NMDAR encephalitis and other autoimmune encephalopathies. Mov Disord. 2014; 29(12): 1539-1542, doi: 10.1002/mds.25999, indexed in Pubmed: 25154478.

72. Granata T, Matricardi S, Ragona F, et al. Pediatric NMDAR encephalitis: A single center observation study with a closer look at movement disorders. Eur J Paediatr Neurol. 2018; 22(2): 301-307, doi: 10.1016/j.ejpn.2018.01.012, indexed in Pubmed: 29396169.

73. Dash D, Ihtisham K, Tripathi M, et al. Proportion and spectrum of movement disorders in adolescent and adult patients of autoimmune encephalitis of non-neoplastic aetiology. J Clin Neurosci. 2019; 59: 185-189, doi: 10.1016/j.jocn.2018.10.076, indexed in Pubmed: 30455136 .
74. Baizabal-Carvallo JF, Stocco A, Muscal E, et al. The spectrum of movement disorders in children with anti-NMDA receptor encephalitis. Mov Disord. 2013; 28(4): 543-547, doi: 10.1002/mds.25354, indexed in Pubmed: 23400857.

75. Edwards MJ, Dale RC, Church AJ, et al. Adult-onset tic disorder, motor stereotypies, and behavioural disturbance associated with antibasal ganglia antibodies. Mov Disord. 2004; 19(10): 1190-1196, doi: 10.1002/mds.20126, indexed in Pubmed: 15390017.

76. Baizabal-Carvallo JF, Jankovic J. Autoimmune and paraneoplastic movement disorders: An update. J Neurol Sci. 2018; 385: 175-184, doi: 10.1016/j.jns.2017.12.035, indexed in Pubmed: 29406902.

77. Twardowschy CA, De Paola L, Teive HAG, et al. Stereotypies after herpetic encephalitis with bitemporal lesions. Mov Disord. 2010; 25(16): 2888-2889, doi: 10.1002/mds.22803, indexed in Pubmed: 20882521.

78. Dale RC, Webster R, Gill D. Contemporary encephalitis lethargica presenting with agitated catatonia, stereotypy, and dystonia-parkinsonism. Mov Disord. 2007; 22(15): 2281-2284, doi: 10.1002/ mds.21664, indexed in Pubmed: 17914719.

79. Picard F, de Sa, Salmon E, et al. Postencephalitic stereotyped involuntary movements responsive to L-Dopa. Movement disorders: official journal of the Movement Disorder Society. 1996 Sep. ; 11(5): 567-70.

80. Jankovic J, Gelineau-Kattner R, Davidson A. Tourette's syndrome in adults. Mov Disord. 2010; 25(13): 2171-2175, doi: 10.1002/ mds.23199, indexed in Pubmed: 20690167.

81. Szejko N, Jakubczyk A, Dunalska A, et al. Dystonic tics in patients with Gilles de la Tourette syndrome. Neurol Neurochir Pol. 2019; 53(5): 335-340, doi: 10.5603/PJNNS.a2019.0046, indexed in Pubmed: 31621889.

82. Szejko N, Jakubczyk A, Janik P. Prevalence and Clinical Correlates of Self-Harm Behaviors in Gilles de la Tourette Syndrome. Front Psychiatry. 2019; 10: 638, doi: 10.3389/fpsyt.2019.00638, indexed in Pubmed: 31543843.

83. Janik P, Szejko N. Aripiprazole in treatment of Gilles de la Tourette syndrome - New therapeutic option. Neurol Neurochir Pol. 2018; 52(1): 84-87, doi: 10.1016/j.pjnns.2017.10.015, indexed in Pubmed: 29154107. 